\title{
ANGPT4 Gene
}

National Cancer Institute

\section{Source}

National Cancer Institute. ANGPT4 Gene. NCI Thesaurus. Code C106488.

This gene plays a role in both vascular development and angiogenesis. 